\title{
Voltammetric Behavior of Zinc Hexacyanoferrate (III) Nanoparticles and Their Application in the Detection of N- Acetylcysteine
}

Vanessa Solfa dos Santos ${ }^{1}$, Vitor Alexandre Maraldi ${ }^{l}$, Kely Silveira Bonfim ${ }^{l}$, Tamires Rocha Souza ${ }^{l}$, Ana Paula Rizzato Nakamura ${ }^{1}$, Maiara de Souza Magossi ${ }^{1}$, Mariana de Souza Magossi ${ }^{1}$, Daniela Silvestrini Fernandes ${ }^{1}$, Devaney Ribeiro do Carmo ${ }^{1 *}$

Faculdade de Engenharia de Ilha Solteira UNESP - Universidade Estadual Paulista "Júlio de Mesquita Filho", Departamento de Física e Química, Av. Brasil, 56. CEP 15385-000, Ilha Solteira, SP, Brazil. Fax: (+55 18) 3742-4868.

"E-mail: docarmo@dfq.feis.unesp.br

doi: $10.20964 / 2017.08 .06$

Received: 22 March 2017 / Accepted: 22 May 2017 / Published: 12 July 2017

The present work reports the voltammetric behavior of Zinc hexacyanoferrate (III) nanoparticles and their application in the detection of $\mathrm{N}$-acetylcysteine. Two distinct ratios of water/formamide 10:0 $(\mathrm{ZnH}-1)$ and 4:6 $(\mathrm{ZnH}-2)$ were studied in the complexation reaction of $\mathrm{Zn}^{2+}$ with $\left[\mathrm{Fe}^{\mathrm{III}}(\mathrm{CN})_{6}\right]^{3-}$. The materials were characterized by Transmission Electron Microscopy (TEM) and Cyclic Voltammetry. The cyclic voltammograms of $\mathrm{ZnH}-1$ and $\mathrm{ZnH}-2$ showed a well-defined redox couple with formal potential $\left.\left(\mathrm{E}^{\theta^{\prime}}\right)=0.94 \pm 0.01 \mathrm{~V}\left(\mathrm{v}=20 \mathrm{mVs}^{-1} ; \mathrm{KCl} 1.0 \mathrm{M}\right)\right)$ attributed to the redox process $\left[\mathrm{Fe}^{\mathrm{II}}(\mathrm{CN})_{6}\right] /\left[\mathrm{Fe}^{\mathrm{III}}(\mathrm{CN})_{6}\right]$ in the presence of $\mathrm{Zn}^{2+}$. The graphite paste electrode modified with $\mathrm{ZnH}-1$ and $\mathrm{ZnH}-2$ presents a sensitive and catalytic oxidation response for the determination of $\mathrm{N}$-acetylcysteine respectively.

Keywords: Zinc Hexacyanoferrate (III) Nanoparticles, Voltammetry, Graphite Paste Electrode, Nacetylcysteine.

\section{$\underline{\text { FULL TEXT }}$}

(C) 2017 The Authors. Published by ESG (www.electrochemsci.org). This article is an open access article distributed under the terms and conditions of the Creative Commons Attribution license (http://creativecommons.org/licenses/by/4.0/). 